\title{
Spirostanol glucosides from the leaves of Cestrum laevigatum $\mathrm{L}$.
}

\author{
Paulo Riceli Vasconcelos Ribeiro ${ }^{a}$, Ana Jérsia Araújo ${ }^{\mathrm{b}}$, Letícia Veras Costa-Lotufo ${ }^{\mathrm{c}}$, Raimundo Braz-Filho ${ }^{\mathrm{d}, \mathrm{e}}$, \\ Hélio Vitoriano Nobre Junior ${ }^{\mathrm{f}}$, Cecília Rocha da Silva ${ }^{\mathrm{f}}$, João Batista de Andrade Neto ${ }^{\mathrm{f}}$, \\ Edilberto Rocha Silveira ${ }^{a}$, Mary Anne Sousa Lima ${ }^{\mathrm{a}, *}$ \\ a Departamento de Química Orgânica e Inorgânica, Centro de Ciências, Universidade Federal do Ceará, CP 12.200, CEP 60.021-940 Fortaleza, CE, Brazil \\ ${ }^{\mathrm{b}}$ Departamento de Farmacologia e Fisiologia, Faculdade de Medicina, Universidade Federal do Ceará, CP 12.200, 60430-270 Fortaleza-CE, Brazil \\ ${ }^{\mathrm{c}}$ Departamento de Farmacologia, Instituto de Ciências Biomédicas, Universidade de São Paulo, CEP 05508-900 São Paulo, SP, Brazil \\ d Laboratório de Ciências Químicas, Universidade Estadual do Norte Fluminense Darcy Ribeiro, 28013602 Campos dos Goytacazes, RJ, Brazil \\ e Departamento de Química, Universidade Federal Rural do Rio de Janeiro, CP 74541, 23890-000 Seropédica, RJ, Brazil \\ ${ }^{\mathrm{f}}$ Departamento de Farmácia, Universidade Federal do Ceará, CP 12.200, 60430-170 Fortaleza, CE, Brazil
}

\section{A R T I C L E I N F O}

\section{Article history:}

Received 22 June 2015

Received in revised form 21 October 2015

Accepted 10 December 2015

Available online 17 December 2015

\section{Keywords:}

Solanaceae

Cestrum laevigatum

Spirostanol glycosides

Antifungal

Cytotoxic

\begin{abstract}
A B S T R A C T
Two new steroidal saponins, (25R)-spirost-5-ene-3 $\beta, 26 \beta$-diol 3-O- $\alpha$-L-rhamnopyranosyl- $(1 \rightarrow 4)-\alpha$-Lrhamnopyranosyl-( $1 \rightarrow 4)$-[( $1 \rightarrow 2)$ - $\alpha$-L-rhamnopyranosyl]- $\beta$-D-glucopyranoside (1) and (25R)-spirost-6ene-3 $\beta, 5 \beta$-diol 3 -O- $\alpha$-L-rhamnopyranosyl- $(1 \rightarrow 4)$ - $\alpha$-L-rhamnopyranosyl- $(1 \rightarrow 4)-[(1 \rightarrow 2)-\alpha$-L-rhamnopyranosyl]- $\beta$-D-glucopyranoside (2), along with the known diosgenin 3-O- $\alpha$-L-rhamnopyranosyl-( $1 \rightarrow$ 4)- $\alpha$-L-rhamnopyranosyl-( $1 \rightarrow 4$ )- $\beta$-D-glucopyranoside (3), chonglouoside SL-5 (4) and Paris saponin Pb (5) were isolated from the leaves of Cestrum laevigatum. The structures of the compounds were determined using spectroscopic analyses including HRESI-MS, 1D and 2D NMR data, followed by comparison with data from the literature. Among them, two are particularly unique, compound $\mathbf{1}$ is the first ${ }^{6} \Delta$-spirostanol saponin and compound 2 has an unusual C-26 hydroxyl in the ${ }^{5} \Delta$-spirostanol skeleton. Antifungal testing showed a potent activity to formosanin $\mathrm{C}$ against Candida albicans and Candida parapsilosis. Evaluation of the cytotoxic activity indicated that compound $\mathbf{1}$ has a moderate activity against HL-60 and SF-295 cell lines, while compound $\mathbf{2}$ were active only against HL-60.
\end{abstract}

(c) 2015 Elsevier Inc. All rights reserved.

\section{Introduction}

Cestrum is the second largest genus of the Solanaceae family, with 150 species distributed in tropical and subtropical America, 50 of which occurring in Brazil [1-2]. As particular to some Solanaceae genera, several species have been reputed as poisonous plants and the search for active compounds revealed a prolific source of bioactive steroids saponins containing spirostanol or furostanol glycoside skeletons [2-7].

Cestrum laevigatum L. is an evergreen shrub native to South America and has been introduced to South Africa. It is widespread into natural grasslands, forests, riparian habitats, and coastal dunes, where is popularly known as "coerana", "lady of the night" and "corana". The dried leaves are used in traditional medicine as treatment for malaria and fever [8], and smoked by the Mapuche Indian of southern Chile as a substitute for cannabis [9]. Although commonly used for ornamental purposes, $C$. laevigatum is consid-

\footnotetext{
* Corresponding author.

E-mail address: mary@dqoi.ufc.br (M.A.S. Lima).
}

ered the most lethal plant to mammals, among the group of common invasive species that cause liver damage. For this reason, is one of toxic plants of greater importance in Brazilian livestock for its wide distribution and economic losses, and its growth is severely controlled or eradicated into pastureland $[10,11]$.

In the course of our search for bioactive natural compounds we report the isolation and structural characterization of two new sapogenins (25R)-spirost-5-ene-3 $\beta, 26 \beta$-diol 3-O- $\alpha$-L-rhamnopyranosyl-( $1 \rightarrow 4)$ - $\alpha$-L-rhamnopyranosyl- $(1 \rightarrow 4)$-[( $1 \rightarrow 2)-\alpha$-L-rhamnopy ranosyl]- $\beta$-D-glucopyranoside (1) and (25R)-spirost-6-ene-3 $\beta, 5 \beta$ diol 3-O- $\alpha$-L-rhamnopyranosyl-( $1 \rightarrow 4)$ - $\alpha$-L-rhamnopyranosyl$(1 \rightarrow 4)$-[(1 $\rightarrow 2)$ - $\alpha$-L-rhamnopyranosyl]- $\beta$-D-glucopyranoside (2) from the leaves of $C$. laevigatum, in addition to the known diosgenin O- $\alpha$-L-rhamnopyranosyl-( $1 \rightarrow 4)$ - $\alpha$-L-rhamnopyranosyl-( $1 \rightarrow 4)$ - $\beta$ D-glucopyranoside (3) [12], chonglouoside SL-5 (4) [13] and formosanin C (5) [14]. The screening for antimicrobial activities against Candida parapsilosis $\left(\right.$ ATCC $^{\circledR} 22019^{\mathrm{TM}}$ ), Candida albicans $\left(\right.$ ATCC $^{\circledR}$ $\left.10231^{\mathrm{TM}}\right)$, Candida krusei $\left(\right.$ ATCC $\left.^{\circledR} 14243^{\mathrm{TM}}\right)$, Pseudomonas aeruginosa (ATCC $^{\circledR}$ 9027 $7^{\mathrm{TM}}$ ), Staphylococcus aureus (ATCC ${ }^{\circledR} 6538^{\mathrm{TM}}$ ) and Bacillus subtilis $\left(\mathrm{ATCC}^{\circledR} 6633^{\mathrm{TM}}\right.$ ), and evaluation of cytotoxicity using human 
promyelocytic leukemia (HL-60), ovarian carcinoma (OVCAR-8), colorectal adenocarcinoma (HCT-116) and glioma (SF-295) cell lines were performed (see Fig. 1).

\section{Experimental}

\subsection{General experimental procedures}

Melting points were obtained on a MetllerToledo-FP82HT and were uncorrected. IR spectra were recorded as $\mathrm{KBr}$ pallets on a Perkin-Elmer FT-IR Spectrum 1000 using KBr. The NMR spectra were performed on Bruker Avance DRX 300 or on Avance DRX500 MHz equipped with an inverse detection probe head and $z$-gradient accessory. The ${ }^{1} \mathrm{H}$ and ${ }^{13} \mathrm{C}$ chemical shifts are expressed in the $\delta$ scale and were referenced to TMS through the residual solvent. High-resolution mass spectra were recorded on a Waters Acquity UPLC system coupled with a Quadrupole/Time-of-Flight system (UPLC/Qtof MSE spectrometer) in the positive mode. The TOF conditions were as follow: source temperature $120^{\circ} \mathrm{C}$; desolvation temperature $350{ }^{\circ} \mathrm{C}$; desolvation gas flow of $350 \mathrm{~L} / \mathrm{h}$; capillary voltage $2 \mathrm{kV}$; collision Energy Ramp $20 \mathrm{eV}$. The mode was acquired from 110 to $1200 \mathrm{Da}$. Optical rotations were obtained on a Perkin-Elmer Q-2000 polarimeter, at $589 \mathrm{~nm}$ and $25^{\circ} \mathrm{C}$. Column chromatography was performed over Sephadex LH-20 (Pharmacia) and SPE C18 cartridge (Phenomenex), while TLC was performed on precoated silica gel aluminum sheets (Merck). The compounds were visualized by UV detection and by spraying with vanillin/perchloric acid/EtOH solution, followed by heating.

\subsection{Plant material}

C. laevigatum L. was collected at the Guaramiranga Mountain, Pacoti, Ceará State, Northeast of Brazil. Voucher specimens (\#38643) were deposited at the Herbário Prisco Bezerra (EAC) and identified by MSc. Edson de Paula Nunes, Departamento de Biologia, Universidade Federal do Ceará, Ceará, Brazil.

\subsection{Extraction and isolation}

Leaves of $C$. laevigatum ( $1.14 \mathrm{~kg}$ ) were pulverized and extracted with EtOH $(3 \times 9.0 \mathrm{~L})$ at room temperature. The solvent was removed under reduced pressure to yield a dark green residue (131.4 g).

Part of EtOH extract (91.0 g) was dissolved in a mixture of $\mathrm{MeOH}: \mathrm{H}_{2} \mathrm{O}(1: 1 \mathrm{v} / \mathrm{v})$ and submitted to liquid-liquid partition chromatography with hexane, $\mathrm{CHCl}_{3}$, EtOAc and $n$-BuOH to give four fractions: hexane $(0.11 \mathrm{~g}), \mathrm{CH}_{2} \mathrm{Cl}_{2}(27.1 \mathrm{~g})$, EtOAc $(11.3 \mathrm{~g})$ and $n$ $\mathrm{BuOH}(32.0 \mathrm{~g})$.

An aliquot of the $n-\mathrm{BuOH}$ fraction (2.0 g) was rechromatographed on Sephadex LH-20 (10.0 g) (column $2.5 \mathrm{~cm} \times 10 \mathrm{~cm})$ to afford forty-five fractions $(3.0 \mathrm{~mL})$ that were pooled together into five resulting sub-fractions after TLC analysis. Sub-fraction F-3 (1.1 g) was further chromatographed on a SPE C18 (5.0 g) cartridge using $\mathrm{MeOH} / \mathrm{H}_{2} \mathrm{O} 1: 1(30.0 \mathrm{~mL}), \mathrm{MeOH} / \mathrm{H}_{2} \mathrm{O}$ 7:3 (3.00 mL), $\mathrm{MeOH} / \mathrm{H}_{2} \mathrm{O}$ 8:2 (40.0 mL), $\mathrm{MeOH} / \mathrm{H}_{2} \mathrm{O}$ 9:1 (30.0 mL) and $\mathrm{MeOH}(50.0 \mathrm{~mL})$, yielding five fractions. Sub-fraction $\mathrm{F}-5$ ( $0.360 \mathrm{~g})$ was submitted to semi-preparative RP-18 HPLC analysis, using $\mathrm{MeOH} / \mathrm{H}_{2} \mathrm{O}(87: 13)$ as eluent, to afford $\mathbf{1}(10.6 \mathrm{mg})$.

An Aliquot of the EtOAc fraction ( $2.1 \mathrm{~g})$ was rechromatographed on Sephadex LH-20 (10.0 g) (column $2.5 \mathrm{~cm} \times 10 \mathrm{~cm}$ ) to give forty sub-fractions $(3.0 \mathrm{~mL})$, which were combined into four resulting sub-fractions according to TLC analysis. Sub-fraction F-3 (0.70 g) which was then chromatographed on a SPE C18 cartridge by elution with $\mathrm{MeOH} / \mathrm{H}_{2} \mathrm{O}$ 1:1 (30.0 mL), $\mathrm{MeOH} / \mathrm{H}_{2} \mathrm{O}$ 7:3 (30.0 mL), $\mathrm{MeOH} / \mathrm{H}_{2} \mathrm{O}$ 8:2 (40.0 mL), $\mathrm{MeOH} / \mathrm{H}_{2} \mathrm{O}$ 9:1 (30.0 mL) and $\mathrm{MeOH}$ $(40.0 \mathrm{~mL})$, yielding five fractions. Fraction F-3 $(0.26 \mathrm{~g})$ was submitted to semi-preparative RP-18 HPLC chromatography, using an isocratic mixture $\mathrm{MeOH} / \mathrm{H}_{2} \mathrm{O}$ 8:1 to afford $2(10.0 \mathrm{mg}), 3(8.0 \mathrm{mg}), 4$ (10.5 mg) and $\mathbf{5}$ (19.5 mg).

\subsection{1. (25R)-spirost-5-ene-3 $\beta, 26 \beta$-diol 3-O- $\alpha$-L-rhamnopyranosyl-}

$(1 \rightarrow 4)-\alpha-L-r h a m n o p y r a n o s y l-(1 \rightarrow 4)-\left[(1 \rightarrow 2)-\alpha-L_{-}\right.$

rhamnopyranosyl]- $\beta$-D-glucopyranoside (1)

White amorphous powder, $\mathrm{mp} 240-242{ }^{\circ} \mathrm{C} ;[\alpha]_{\mathrm{D}}^{20}-172.8$ (c 0.10, $\mathrm{MeOH})$; Rf $0.22\left(\mathrm{CH}_{2} \mathrm{Cl}_{2} / \mathrm{MeOH} 25 \%\right) ;{ }^{1} \mathrm{H}$ and ${ }^{13} \mathrm{C}$ NMR data: see

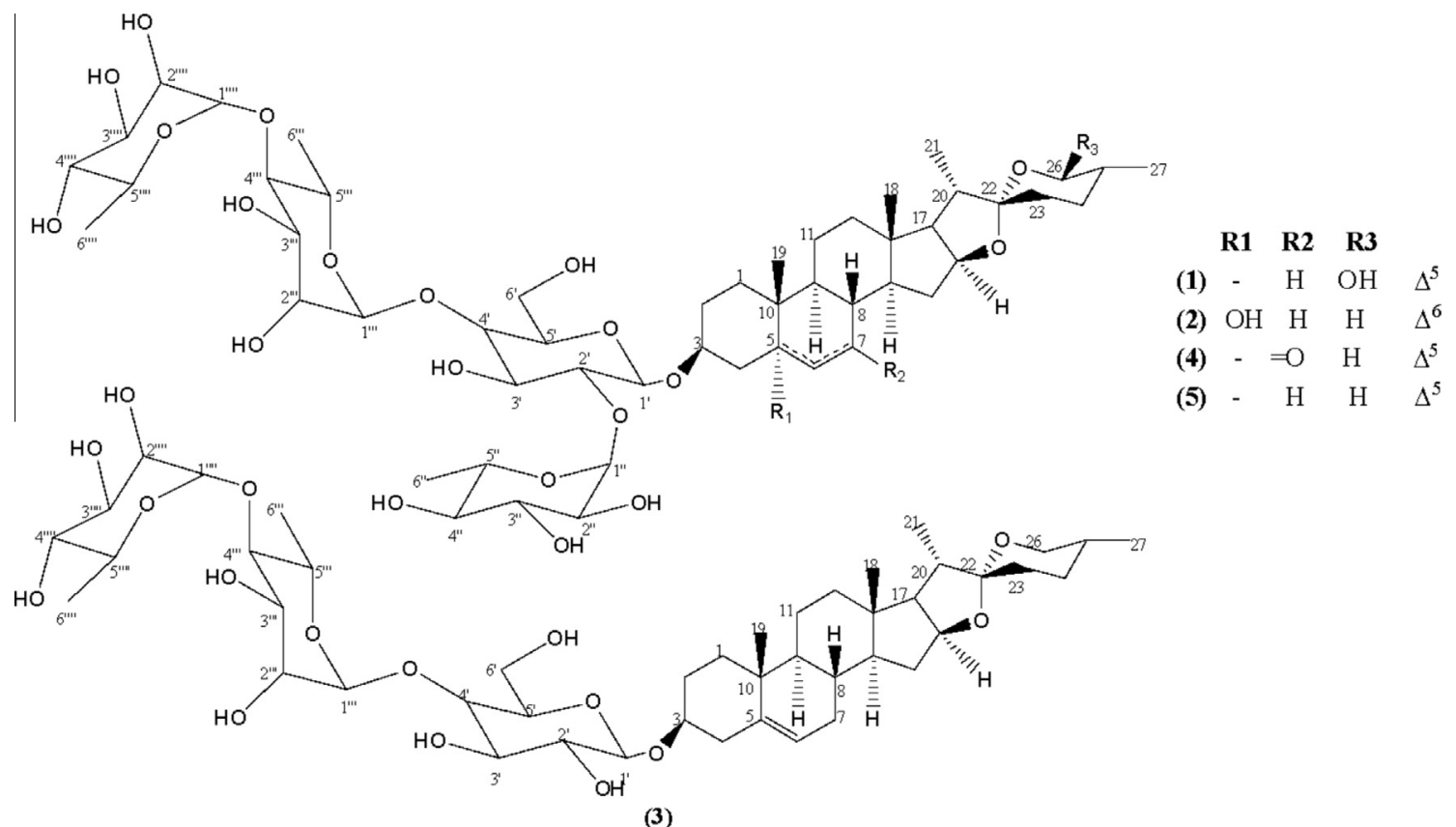

Fig. 1. Structures of compounds 1-5. 
Table 1

NMR spectral data of compounds 1 and $2\left({ }^{1} \mathrm{H}-500 \mathrm{MHz} ;{ }^{13} \mathrm{C}-125 \mathrm{MHz} ; \mathrm{CD}_{3} \mathrm{OD}\right)$

\begin{tabular}{|c|c|c|c|c|}
\hline \multirow[t]{2}{*}{ Position } & \multicolumn{2}{|l|}{1} & \multicolumn{2}{|l|}{2} \\
\hline & $\delta_{\mathrm{C}}$ & $\delta_{\mathrm{H}}$ & $\delta_{\mathrm{C}}$ & $\delta_{\mathrm{H}}$ \\
\hline \multirow[t]{2}{*}{1} & 38.1 & $1.82(\mathrm{~m})$ & 29.6 & $1.68(\mathrm{~m})$ \\
\hline & & $1.02(\mathrm{~m})$ & & $1.40(\mathrm{~m})$ \\
\hline \multirow[t]{2}{*}{2} & 30.6 & $1.90(\mathrm{~m})$ & 32.3 & $1.79(\mathrm{~m})$ \\
\hline & & $1.60(\mathrm{~m})$ & & $1.57(\mathrm{~m})$ \\
\hline 3 & 79.4 & $3.54(\mathrm{~m})$ & 75.2 & $4.17(\mathrm{~m})$ \\
\hline \multirow[t]{2}{*}{4} & 39.6 & $2.44 \mathrm{dd}(12.5,3.0)$ & 39.3 & $2.50(\mathrm{~m})$ \\
\hline & & $2.35 \mathrm{t}(12.5)$ & & $2.36 \mathrm{t}(12.7)$ \\
\hline 5 & 142.1 & - & 84.2 & - \\
\hline 6 & 122.8 & $5.38 \mathrm{~d}(4.4)$ & 134.4 & $5.72 \mathrm{~d}(10.2)$ \\
\hline \multirow[t]{2}{*}{7} & 33.3 & $2.00(\mathrm{~m})$ & 131.7 & $5.62 \mathrm{dd}(10.2,2.1)$ \\
\hline & & $1.58(\mathrm{~m})$ & & \\
\hline 8 & 33.0 & $1.28(\mathrm{~m})$ & 39.8 & $2.17(\mathrm{~m})$ \\
\hline 9 & 51.2 & $0.90(\mathrm{~m})$ & 45.4 & $1.80(\mathrm{~m})$ \\
\hline 10 & 38.2 & - & 39.6 & - \\
\hline \multirow[t]{2}{*}{11} & 22.2 & $1.55(\mathrm{~m})$ & 21.7 & $1.54(\mathrm{~m})$ \\
\hline & & & & $1.37(\mathrm{~m})$ \\
\hline \multirow[t]{2}{*}{12} & 41.1 & $1.78(\mathrm{~m})$ & 41.8 & $1.75(\mathrm{~m})$ \\
\hline & & $1.20(\mathrm{~m})$ & & $1.19(\mathrm{~m})$ \\
\hline 13 & 41.6 & - & 42.7 & - \\
\hline \multirow[t]{3}{*}{14} & 58.0 & $1.18(\mathrm{~m})$ & 54.7 & $1.40(\mathrm{~m})$ \\
\hline & 15 & $1.70(\mathrm{~m})$ & 32.4 & $2.10(\mathrm{~m})$ \\
\hline & & $1.58(\mathrm{~m})$ & & $1.40(\mathrm{~m})$ \\
\hline 16 & 82.5 & $4.58(\mathrm{~m})$ & 82.3 & $4.40(\mathrm{~m})$ \\
\hline 17 & 63.9 & $1.82(\mathrm{~m})$ & 63.5 & $1.80(\mathrm{~m})$ \\
\hline 18 & 16.9 & $0.80(\mathrm{~s})$ & 17.0 & $0.82(\mathrm{~s})$ \\
\hline 19 & 20.0 & $1.04(\mathrm{~s})$ & 16.0 & $0.98(\mathrm{~s})$ \\
\hline 20 & 43.1 & $1.92(\mathrm{~m})$ & 42.8 & $1.92(\mathrm{~m})$ \\
\hline 21 & 15.0 & $1.01 \mathrm{~d}(6.5)$ & 14.9 & $0.96 \mathrm{~d}(6.9)$ \\
\hline 22 & 113.8 & - & 110.6 & - \\
\hline \multirow[t]{2}{*}{23} & 32.9 & $2.00(\mathrm{~m})$ & 33.2 & $2.50(\mathrm{~m})$ \\
\hline & & $1.50(\mathrm{~m})$ & & $1.50(\mathrm{~m})$ \\
\hline \multirow[t]{2}{*}{24} & 29.2 & $1.60(\mathrm{~m})$ & 29.8 & $1.90(\mathrm{~m})$ \\
\hline & & $1.50(\mathrm{~m})$ & & $1.60(\mathrm{~m})$ \\
\hline 25 & 38.2 & $1.32(\mathrm{~m})$ & 31.3 & $1.60(\mathrm{~m})$ \\
\hline \multirow[t]{2}{*}{26} & 97.2 & $4.52 \mathrm{~d}(8.0)$ & 67.9 & $3.45(\mathrm{~m})$ \\
\hline & & & & $3.38(\mathrm{~m})$ \\
\hline 27 & 17.3 & $0.93 \mathrm{~d}(8.0)$ & 17.6 & $0.79 \mathrm{~d}(6.4)$ \\
\hline$\beta$-D-glyco & anosyl( 1 & & & \\
\hline $1^{\prime}$ & 100.6 & $4.49 \mathrm{~d}(8.0)$ & 100.8 & $4.50 \mathrm{~d}(7.8)$ \\
\hline $2^{\prime}$ & 79.5 & $3.40(\mathrm{~m})$ & 79.4 & $3.40(\mathrm{~m})$ \\
\hline $3^{\prime}$ & 78.1 & $3.56(\mathrm{~m})$ & 78.0 & $3.58(\mathrm{~m})$ \\
\hline $4^{\prime}$ & 79.6 & $3.52(\mathrm{~m})$ & 79.9 & $3.54(\mathrm{~m})$ \\
\hline $5^{\prime}$ & 76.8 & $3.30(\mathrm{~m})$ & 76.6 & $3.32(\mathrm{~m})$ \\
\hline $6^{\prime}$ & 62.1 & $3.80(\mathrm{~m})$ & 62.0 & $3.81(\mathrm{~m})$ \\
\hline & & $3.65(\mathrm{~m})$ & & $3.68(\mathrm{~m})$ \\
\hline$\alpha$-L-rham & yranos & $\rightarrow 2)$ & & \\
\hline $1^{\prime \prime}$ & 102.5 & $5.18 \mathrm{~d}(1.5)$ & 102.3 & $5.20(s)$ \\
\hline $2^{\prime \prime}$ & 73.0 & $3.78(\mathrm{~m})$ & 72.0 & $3.94(\mathrm{~m})$ \\
\hline $3^{\prime \prime}$ & 72.5 & $3.65(\mathrm{~m})$ & 72.3 & $3.61 \mathrm{dd}(9.5,3.2)$ \\
\hline $4^{\prime \prime}$ & 74.0 & $3.38(\mathrm{~m})$ & 73.8 & $3.40(\mathrm{~m})$ \\
\hline $5^{\prime \prime}$ & 69.2 & $4.05(\mathrm{~m})$ & 69.7 & $4.12(\mathrm{~m})$ \\
\hline $6^{\prime \prime}$ & 18.7 & $1.29 \mathrm{~d}(6.5)$ & 17.9 & $1.25 \mathrm{~d}(6.0)$ \\
\hline$\alpha-$-rham & yranosy & $\rightarrow 4)$ & & \\
\hline $1^{\prime \prime \prime}$ & 102.8 & $4.83 \mathrm{~d}(1.5)$ & 102.6 & $4.83 \mathrm{~d}(1.3)$ \\
\hline $2^{\prime \prime \prime}$ & 72.5 & $3.93(\mathrm{~m})$ & 72.8 & $3.79(\mathrm{~m})$ \\
\hline $3^{\prime \prime \prime}$ & 73.0 & $3.76(\mathrm{~m})$ & 72.9 & $3.75(9.1,3.1)$ \\
\hline $4^{\prime \prime \prime}$ & 81.0 & $3.57(\mathrm{~m})$ & 80.8 & $3.55(\mathrm{~m})$ \\
\hline $5^{\prime \prime \prime}$ & 70.0 & $4.14(\mathrm{~m})$ & 69.2 & $4.03(\mathrm{~m})$ \\
\hline $6^{\prime \prime \prime}$ & 18.0 & $1.24 \mathrm{~d}(5.5)$ & 18.6 & $1.29 \mathrm{~d}(6.2)$ \\
\hline$\alpha-L-r h a m$ & yranosy & $\rightarrow 4)$ & & \\
\hline $1^{\prime \prime \prime \prime}$ & 103.3 & $5.18 \mathrm{~d}(1.5)$ & 103.0 & $5.19(\mathrm{~s})$ \\
\hline $2^{\prime \prime \prime \prime}$ & 72.5 & $3.93(\mathrm{~m})$ & 72.0 & $3.94(\mathrm{~m})$ \\
\hline $3^{\prime \prime \prime \prime \prime}$ & 72.3 & $3.60(\mathrm{~m})$ & 72.3 & $3.68(\mathrm{~m})$ \\
\hline $4^{\prime \prime \prime \prime}$ & 74.1 & $3.38(\mathrm{~m})$ & 73.9 & $3.40(\mathrm{~m})$ \\
\hline $5^{\prime \prime \prime \prime}$ & 70.6 & $3.70(\mathrm{~m})$ & 70.4 & $3.70(\mathrm{~m})$ \\
\hline $6^{\prime \prime \prime \prime}$ & 18.1 & $1.25 \mathrm{~d}(6.5)$ & 18.0 & $1.25 \mathrm{~d}(6.0)$ \\
\hline
\end{tabular}

Table 1; IR (KBr) 3355; 2928; 1640; $1452 ; 1036 \mathrm{~cm}^{-1}$. HRESIMS $m / z: 1031.5468[\mathrm{M}+\mathrm{H}]^{+}\left(\right.$calcd for $\left.\mathrm{C}_{51} \mathrm{H}_{83} \mathrm{O}_{21}[\mathrm{M}+\mathrm{H}], 1031.5427\right)$.
2.3.2. (25R)-spirost-6-ene-3 $\beta, 5 \beta$-diol 3-O- $\alpha$-L-rhamnopyranosyl-( $1 \rightarrow$ 4)- $\alpha$-L-rhamnopyranosyl- $(1 \rightarrow 4)-[(1 \rightarrow 2)-\alpha-L$-rhamnopyranosyl $]-\beta-$ D-glucopyranoside (2)

White amorphous powder, $\mathrm{mp} 178-179{ }^{\circ} \mathrm{C} ;[\alpha]_{\mathrm{D}}^{20}-132.7$ (c 0.16 , $\mathrm{MeOH})$; Rf $0.20\left(\mathrm{CH}_{2} \mathrm{Cl}_{2} / \mathrm{MeOH} 25 \%\right) ;{ }^{1} \mathrm{H}$ and ${ }^{13} \mathrm{C}$ NMR data: see Table 1 ; IR (KBr) 3362; 2928; 1653; 1453; 1037. HRESIMS $m / z$ : $1031.5427[\mathrm{M}+\mathrm{H}]^{+}\left(\right.$calcd for $\left.\mathrm{C}_{51} \mathrm{H}_{83} \mathrm{O}_{21}[\mathrm{M}+\mathrm{H}], 1031.5427\right)$.

2.3.3. (25R)-spirost-5-ene-3 $\beta$-ol 3-O- $\alpha$-L-rhamnopyranosyl-( $1 \rightarrow 4)$ $\alpha$-L-rhamnopyranosyl-(1 $\rightarrow 4)$ - $\beta$-D-glucopyranoside (3)

$[\alpha]_{\mathrm{D}}^{20}-55.5^{\circ}(c 0.09 ; \mathrm{MeOH})\left\{[\alpha]_{\mathrm{D}}^{24}-62.0(c\right.$ 0.09; MeOH) [15] $\} ; \mathrm{Rf}$ $0.50\left(\mathrm{CH}_{2} \mathrm{Cl}_{2} / \mathrm{MeOH} 25 \%\right)$.

2.3.4. (25R)-7-oxo-espirost-5-ene-3 $\beta$-ol 3-O- $\alpha$-L-rhamnopyranosyl$(1 \rightarrow 4)-\alpha$-L-rhamnopyranosyl- $(1 \rightarrow 4)-[(1 \rightarrow 2)-\alpha-L-$ rhamnopyranosyl $]-$ $\beta$-D-glucopyranoside (4)

$[\alpha]_{\mathrm{D}}^{20}-115.8^{\circ}$ ( с 0.11; MeOH) $\left\{[\alpha]_{\mathrm{D}}^{15}-32.8^{\circ}\right.$ ( c 0.12; MeOH) [13]\}; Rf $0.23\left(\mathrm{CH}_{2} \mathrm{Cl}_{2} / \mathrm{MeOH} 25 \%\right)$.

2.3.5. (25R)-espirost-5-ene-3 $\beta$-ol 3-0- $\alpha$-L-rhamnopyranosyl-( $1 \rightarrow 4)$ $\alpha$-L-rhamnopyranosyl- $(1 \rightarrow 4)-[(1 \rightarrow 2)-\alpha-L$-rhamnopyranosyl $]-\beta-D-$ glucopyranoside (5)

$[\alpha]_{\mathrm{D}}^{20}-116.7^{\circ}$ ( c 0.20; $\left.\mathrm{MeOH}\right)\left\{[\alpha]_{\mathrm{D}}^{21}-118.6^{\circ}\right.$ ( c 0.20; MeOH) [15]\}; Rf $0.23\left(\mathrm{CH}_{2} \mathrm{Cl}_{2} / \mathrm{MeOH} 25 \%\right)$.

\subsection{Acid hydrolysis and sugar analysis}

Compounds 1 and 2 (5.0 mg) were dissolved in $2 \mathrm{M} \mathrm{HCl}$ (dioxane $/ \mathrm{H}_{2} \mathrm{O}, 1: 1,2 \mathrm{~mL}$ ) and stirred at $90^{\circ} \mathrm{C}$ for $2 \mathrm{~h}$. After cooling, the reaction mixture was neutralized with solution of $1 \mathrm{M} \mathrm{NaOH}$, extracted with $\mathrm{CH}_{2} \mathrm{Cl}_{2}(3 \times 5 \mathrm{~mL})$, and the aqueous layer was evaporated to give a mixture of monosaccharides. The residue was dissolved in hexamethyldisilazane/trimethylchlorosilane/pyridine (3:1:9), and stirred at $70{ }^{\circ} \mathrm{C}$ for $60 \mathrm{~min}$. The supernatants $(3 \mu \mathrm{L})$ were analyzed by GC Agilent model GC-789/MSD-5977A (quadrupole), under the following conditions: CP-ChiraSil-L-Val column, $0.25 \mathrm{~mm} \times 25 \mathrm{~m}$; temperatures for detector and injector 150 and $200{ }^{\circ} \mathrm{C}$ respectively; temperature gradient system for the oven, $100^{\circ} \mathrm{C}$ for $1 \mathrm{~min}$ and then raised to $180^{\circ} \mathrm{C}$; rate $5^{\circ} \mathrm{C} / \mathrm{min}$ kept for $5 \mathrm{~min}$. The configurations of sugars were determined by comparison of the retentions times of the corresponding derivatives with those of standards treated simultaneously with same silylating reagents (L-rhamnose 11.15 and D-glucose 16.57). Peaks of the hydrolysates of $\mathbf{1}$ and $\mathbf{2}$ were detected at 11.20 (L-rhamnose) and 16.57 (D-glucose). Co-injection of each hydrolysate with standard D-glucose and L-rhamnose gave single peaks.

\subsection{Cytotoxic activity}

The tested tumor cell lines (colorectal adenocarcinoma HCT116, ovarian carcinoma OVCAR-8, human promyelocytic leukemia HL-60 and glioma SF-295) were kindly donated by the National Cancer Institute (Bethesda, MD, USA). Cells were maintained in RPMI 1640 medium supplemented with $10 \%$ fetal bovine serum, $2 \mathrm{mM}$ glutamine, $100 \mathrm{U} \mathrm{mL}^{-1}$ penicillin, and $100 \mu \mathrm{g} \mathrm{mL}^{-1}$ streptomycin at $37^{\circ} \mathrm{C}$ with $5 \% \mathrm{CO}_{2}$. The cytotoxicity of the isolated compounds was tested the against tumor cell lines using the 3-(4,5dimethyl-2-thiazolyl-2,5-diphenyl-2H-tetrazolium bromide) (MTT) (Sigma Aldrich Co., St. Louis, MO/USA) reduction assay [16]. Cells were plated in 96 -well plates $\left(10^{5}\right.$ cells per well for adherent cells or $3 \times 10^{5}$ cells per well for suspended cells in $100 \mu \mathrm{L}$ of medium) and compounds $\left(0.05-25 \mu \mathrm{g} \mathrm{mL}^{-1}\right)$ were dissolved in DMSO, added to each well using the HTS - high-throughput screening-biomek 3000-Beckman Coulter (Inc. Fullerton, California, USA), and incubated for $72 \mathrm{~h}$. Doxorubicin was used as 
the positive control. Control groups received the same amount of DMSO. After $69 \mathrm{~h}$ of incubation, the supernatant was replaced by fresh medium containing MTT $\left(0.5 \mathrm{mg} \mathrm{mL}^{-1}\right)$. Three hours later, the MTT formazan product was dissolved in $150 \mu \mathrm{L}$ of DMSO, and the absorbance was measured at $595 \mathrm{~nm}$ (DTX 880 Multimode Detector, Beckman Coulter, Inc. Fullerton, CA, USA).

\subsection{Antimicrobial activity}

\subsubsection{In vitro antibacterial activity}

Tests were performed according to the M02-A11 (CLSI, 2012) protocol with modifications [17]. Wells with $6 \mathrm{~mm}$ diameter were made in the agar overlay of the Petri dish [18]. To those wells, a volume of $20 \mu \mathrm{L}\left(1000 \mu \mathrm{g} \mathrm{mL}^{-1}\right)$ of the obtained compounds was applied. The plates were incubated for $20 \mathrm{~h}$ at $35^{\circ} \mathrm{C}$. The solvents and diluents used in the compounds dissolution were used as negative control.

\subsubsection{In vitro antifungal activity}

The broth microdilution (BMD) antifungal susceptibility test was performed according to M27-A3 protocol using RPMI broth (pH 7.0) buffered with 0.165 M MOPS [3-( $N$-morpholino)propanesulfonic acid] (Sigma-Aldrich, St Louis, MO, USA) [19]. Compounds were dissolved in dimethyl sulfoxide (DMSO; Sigma-Aldrich) and tested at concentrations ranging from 1.95 to $1000 \mu \mathrm{g} \mathrm{mL}^{-1}$. The yeasts and compounds were incubated in 96-well culture plates at $35^{\circ} \mathrm{C}$ for $24 \mathrm{~h}$ and the results were examined visually. The minimum inhibitory concentration (MIC) of each compound was determined as the concentration that inhibited $50 \%$ of fungal growth.

\section{Results and discussion}

Compound 1 was isolated as a white solid. Its molecular formula was defined as $\mathrm{C}_{51} \mathrm{H}_{82} \mathrm{O}_{21}$ by the protonated molecular ion peak at $m / z 1031.5468[\mathrm{M}+\mathrm{H}]$ (calcd 1031.5427) in the HRESIMS spectrum. The IR spectrum displayed an absorption band relative to hydroxyl at $3355 \mathrm{~cm}^{-1}$.

The ${ }^{1} \mathrm{H}$ NMR spectrum revealed the presence of two singlet methyls at $\delta_{\mathrm{H}} 0.80(\mathrm{~s}, \mathrm{H}-18), 1.04(\mathrm{~s}, \mathrm{H}-19)$ and five doublets at $\delta_{\mathrm{H}} 0.93(J=8.0 \mathrm{~Hz}, \mathrm{H}-27), 1.01(J=6.5 \mathrm{~Hz}, \mathrm{H}-21), 1.24(J=5.5 \mathrm{~Hz}$, $\left.\mathrm{H}-6^{\prime \prime \prime}\right), 1.29\left(\mathrm{~d}, J=6.5 \mathrm{~Hz}, \mathrm{H}-6^{\prime \prime}\right)$ and $1.25\left(J=6.5 \mathrm{~Hz}, \mathrm{H}-6^{\prime \prime \prime \prime}\right)$, besides a vinyl hydrogen attached of a trissubstituted double bond at $\delta_{\mathrm{H}}$ $5.38(\mathrm{H}-6, J=4.4 \mathrm{~Hz})$, and several signals in the range at $\delta_{\mathrm{H}}$ 3.30-5.18, indicating 1 to be a steroidal glycoside.

The ${ }^{13} \mathrm{C}$ NMR spectrum displayed forty-four signals, some of which were oxygenated and superimposed and twenty-seven others attributable to the aglycone moiety. The presence of characteristic signals related to one spiro acetal carbon at $\delta_{\mathrm{C}} 113.8(\mathrm{C}-22)$, besides two olefinics at $\delta_{\mathrm{C}} 142.1$ (C-5) and 122.8 (C-6), after comparison to the literature data for steroidal sapogenins containing a $\Delta^{5}$-spirostanol skeleton, showed a good match with those related to gitogenin [20]. The only difference was the replacement of the signal of the oxymethylene C-26 in gitogenin at $\delta_{\mathrm{C}} 67.1$, for one additional dioxymethine carbon at $\delta_{\mathrm{C}} 97.2$ in 1, suggesting hydroxylation of $\mathrm{C}-26$ on the ring $\mathrm{F}$.

All proton and carbon signals were fully assigned heteronuclear single-quantum coherence (HSQC) and HMBC spectra (Table 1). The four sugar units were characterized by the HSQC correlations of the signals of the acetal carbon at $\delta_{\mathrm{C}} 100.6\left(\mathrm{C}-1^{\prime}\right)$ with the anomeric proton at $\delta_{\mathrm{H}} 4.49\left(\mathrm{~d}, J=8.0 \mathrm{~Hz}, \mathrm{H}-1^{\prime}\right)$, the carbon at $\delta_{\mathrm{C}}$ $102.8\left(\mathrm{C}-1^{\prime \prime \prime}\right)$ with the hydrogen at $\delta_{\mathrm{H}} 4.83\left(\mathrm{~d}, J=1.5 \mathrm{~Hz}, \mathrm{H}-1^{\prime \prime \prime}\right)$, while the two others at $\delta_{\mathrm{C}} 102.5\left(\mathrm{C}-1^{\prime \prime}\right)$ and $103.3\left(\mathrm{C}-1^{\prime \prime \prime \prime}\right)$ showed correlation with the signal at $\delta_{\mathrm{H}} 5.18(\mathrm{~d}, J=1.5 \mathrm{~Hz})$. This suggestion was corroborated by sequential loss of the four hexoses moieties showed by the fragment ion peaks at $m / z$ at $885.4839,739.4393$, 557.3475 and 413.3046 in the HRESIMS spectrum. The identity of the monosaccharides as one D-glucose and three L-rhamnose units were carried out by NMR analyses and comparison with the literature data [20], whose absolute configuration of glucose was determined as $\mathrm{D}$ and those of the rhamnoses as $\mathrm{L}$, on the basis of the acid hydrolysis and HPLC analysis as described. A $\beta$-anomeric configuration of the glucopyranosyl moiety was supported by the relatively large vicinal coupling constant value of $8.0 \mathrm{~Hz}$ for the anomeric proton at $\delta_{\mathrm{H}} 4.49\left(\mathrm{H}-1^{\prime}\right)$, while the $\alpha$-anomeric configuration of the three rhamnopyranosyl units at $\delta_{\mathrm{H}} 4.83\left(\mathrm{H}-1^{\prime \prime \prime}\right)$ and 5.18 $\left(\mathrm{H}-1^{\prime \prime}\right.$ and $\left.\mathrm{H}-1^{\prime \prime \prime \prime}\right)$, was deduced by the value of $J=1.5 \mathrm{~Hz}$.

The HMBC spectrum permitted to establish the sequence of all sugar units by long-range correlations between the proton signal at $\delta_{\mathrm{H}} 5.18\left(\mathrm{H}-1^{\prime \prime \prime \prime}\right)$ of the first rhamnopyranose unit with the carbon at $\delta_{\mathrm{C}} 81.0\left(\mathrm{C}-4^{\prime \prime \prime}\right)$ of the second, whose anomeric hydrogen at $\delta_{\mathrm{H}} 4.83$ $\left(\mathrm{H}-1^{\prime \prime \prime}\right)$ showed correlation with the carbon at $\delta_{\mathrm{C}} 79.6\left(\mathrm{C}-4^{\prime}\right)$ of the glycopyranose. The anomeric hydrogen at $\delta_{\mathrm{H}} 5.18\left(\mathrm{H}-1^{\prime \prime}\right)$ of third rhamnopyranose also showed correlation with the glycopyranose moiety through the carbon at $\delta_{\mathrm{C}} 79.5\left(\mathrm{C}-2^{\prime}\right)$. Finally, the anomeric hydrogen of the glycopyranose unit at $\delta_{\mathrm{H}} 4.49\left({\left.\mathrm{H}-1^{\prime}\right)}^{\prime}\right.$ showed correlation with the $\mathrm{C}-3$ carbon of the aglicone portion at $\delta_{\mathrm{C}} 79.3(\mathrm{C}-3)$. These findings confirmed the attachment sequence of the sugar chain at $\mathrm{C}-3$ to be $3-0-\alpha-\mathrm{L}-$ rhamnopyranosyl- $(1 \rightarrow 4)$ $\alpha$-L-rhamnopyranosyl- $(1 \rightarrow 4)$-[( $1 \rightarrow 2)$ - $\alpha$-L-rhamnopyranosyl]- $\beta$-Dglucopyranoside. The locations of the 26-hydroxyl and 27-methyl group equatorially positioned were confirmed by long range correlations between the methyl group at $\delta_{\mathrm{H}} 0.93\left(\mathrm{CH}_{3}-27\right)$ with the acetal carbon at $\delta_{\mathrm{C}} 97.2$ (C-26), and based on the large value of the coupling constant of $8.0 \mathrm{~Hz}$ observed for the dioxymethine hydrogen at $\delta_{\mathrm{H}} 4.52(\mathrm{H}-26)$. Thus, the structure of 1 was elucidated as the new (25R)-spirost-5-ene-3 $\beta, 26 \beta$-diol 3-O- $\alpha$-L-rhamnopyranosyl- $(1 \rightarrow 4)-\alpha$-L-rhamnopyranosyl- $(1 \rightarrow 4)$-[( $1 \rightarrow 2)-\alpha$-L-rhamnopyranosyl]- $\beta$-D-glucopyranoside.

Compound 2 was isolated as a yellow resin. The support for a spirostanol steroid skeleton came from the comparative analysis of its MS and NMR data with those observed for compound 1. It had also a molecular formula $\mathrm{C}_{51} \mathrm{H}_{83} \mathrm{O}_{21}$ on the basis of HRESIMS ions peak at $\mathrm{m} / \mathrm{z} 1031.5427$ (calcd 1031.5427).

The ${ }^{1} \mathrm{H}$ NMR spectral data of $\mathbf{2}$ were also quite similar to those of $\mathbf{1}$, except the by the absence of the dioxymethyne hydrogen at $\delta_{\mathrm{H}}$ $4.52(\mathrm{H}-26)$ observed in $\mathbf{1}$, and the presence of an additional vicinal vinyl hydrogens as a pair of doublets at $\delta_{\mathrm{H}} 5.62(\mathrm{dd}, J=10.2,2.1 \mathrm{~Hz}$, $\mathrm{H}-7$ ) and 5.72 (d, $J=10.2 \mathrm{~Hz}, \mathrm{H}-6)$ in 2 , instead of the single signal in 1 at $\delta_{\mathrm{H}} 5.38$ (H-6), indicating that the trissubstituted double bond in $\mathbf{1}$ was rearranged to a cis configuration in $\mathbf{2}$.

In the ${ }^{13} \mathrm{C}$ NMR spectrum of $\mathbf{2}$ was identified an additional oxygenated quaternary carbon at $\delta_{\mathrm{C}} 84.2$ (C-5), and similar signals related to the four sugar anomeric carbons at $\delta_{\mathrm{C}} 100.8\left(\mathrm{C}-1^{\prime}\right)$, $102.3\left(\mathrm{C}-1^{\prime \prime}\right), 102.6\left(\mathrm{C}-1^{\prime \prime \prime}\right)$ and $103.0\left(\mathrm{C}-1^{\prime \prime \prime \prime}\right)$ showing HSQC correlations with corresponding hydrogens signals at $\delta_{\mathrm{H}} 4.50(\mathrm{~d}$, $J=7.8 \mathrm{~Hz}, \mathrm{H}-1^{\prime}$ ), 5.20 (d, $J=1.5 \mathrm{~Hz}, \mathrm{H}-1^{\prime \prime}$ ), 4.83 (d, $J=1.3 \mathrm{~Hz}, \mathrm{H}-1^{\prime \prime \prime}$ ) and $5.19\left(\mathrm{~d}, J=1.5 \mathrm{~Hz}, \mathrm{H}-1^{\prime \prime \prime \prime}\right)$, respectively, in addition to deoxygenated monohydrogenated carbon at $\delta_{\mathrm{C}} 110.6$ (C-22). Moreover, the cis disubstituted double bond was confirmed by the two signals of unsaturated monohydrogenated carbons at $\delta_{\mathrm{C}} 131.7$ (C-7) and 134.4 (C-6), showing correlations with the hydrogens at $\delta_{\mathrm{H}} 5.62$ (H-7) and $5.72(\mathrm{H}-6)$, respectively.

The assignments of the signals related to the sugar carbons, as well as their sequence were established by long-range connectivities in the HMBC spectrum (Table 1). Moreover, the location of the hydroxylated carbon at C-5 and the $\Delta^{6}$-double bond was determined by the three bond correlations of the hydrogens of the methyl group at $\delta_{\mathrm{H}} 0.98\left(\mathrm{CH}_{3}-19\right)$ and olefin proton at $\delta_{\mathrm{H}} 5.62$ $(\mathrm{H}-7)$ with the oxygenated carbon at $\delta_{\mathrm{C}} 84.2(\mathrm{C}-5)$, besides correlations of the hydrogens at $\delta_{\mathrm{H}} 2.17(\mathrm{H}-8)$ and $2.50(\mathrm{H}-4)$ with the 
Table 2

Cytotoxicity of compounds against four human cancer cell lines. ${ }^{a}$

\begin{tabular}{|c|c|c|c|c|}
\hline Compounds & HL-60 & OVCAR-8 & НCT-116 & SF-295 \\
\hline 1 & $6.5(5.2-8.1)$ & $10.3(5.4-19.9)$ & $10.1(4.5-23.0)$ & $7.7(4.2-14.1)$ \\
\hline 2 & $7.3(6.7-7.9)$ & $15.3(11.9-19.6)$ & $11.4(9.6-13.5)$ & $12.9(10.8-15.4)$ \\
\hline 3 & $>25$ & $>25$ & $>25$ & $>25$ \\
\hline 4 & $8.2(7.4-9.1)$ & $10.8(9.4-12.4)$ & $8.6(7.6-9.9)$ & $6.9(5.6-8.4)$ \\
\hline 5 & $0.6(0.4-0.7)$ & $2.4(1.9-2.9)$ & $1.01(0.74-1.37)$ & $1.3(1.0-1.6)$ \\
\hline Doxorubicin $^{\text {b }}$ & $0.02(0.01-0.02)$ & $0.3(0.2-0.3)$ & $0.1(0.1-0.2)$ & $0.2(0.2-0.3)$ \\
\hline
\end{tabular}

a Results are expressed as $\mathrm{IC}_{50}$ values in $\mu \mathrm{M}$ and means \pm standard deviation of three independent replicates.

b Positive control.

unsaturated carbon at $\delta_{\mathrm{C}} 134.4$ (C-6). The shielding effects of the ${ }^{13} \mathrm{C}$ NMR signals observed for the carbons $\delta_{\mathrm{C}} 29.6$ (C-1), 75.2 (C-3) and 45.4 (C-9) as compared with those to compound 1 , suggested that these carbons were subjected to a $\gamma$-gauche shielding effect of the C-5 hydroxyl group, that consequently was axially oriented. In addition, the methyl group equatorially-oriented was determined by the diagnostic assignments observed for the carbons at C-23, C-24, C-25 and C-26 in comparison with those reported by Agrawal et al. [19].

As observed in $\mathbf{1}$, the glucopyranosyl moiety presented a $\beta$-anomeric configuration based on the large vicinal coupling constant value of $7.8 \mathrm{~Hz}$ of the anomeric proton at $\delta_{\mathrm{H}} 4.50\left(\mathrm{H}-1^{\prime}\right)$, while the three rhamnopyranosyl units have an $\alpha$-anomeric configuration by the value of $J=1.5 \mathrm{~Hz}$, for the hydrogens at $\delta_{\mathrm{H}}$ $4.83\left(\mathrm{H}-1^{\prime \prime \prime}\right), 5.19\left(\mathrm{H}-1^{\prime \prime \prime \prime}\right)$ and $5.20\left(\mathrm{H}-1^{\prime \prime}\right)$. The absolute configuration of the glucose unit was also determined as $\mathrm{D}$ and that of rhamnose as L, through the acid hydrolysis and the HPLC analysis. In addition, the diagnostic signals at $m / z$ 1013.5504, 867.4950, $721.4130,575.3622$ and 413.3011 in the HRESIMS, showed the subsequent loss of $\mathrm{H}_{2} \mathrm{O}$ and the four sugar moieties and confirmed the proposed structure.

Thus, the structure of $\mathbf{2}$ was elucidated as the (25R)-spirost-6ene-3 $\beta, 5 \beta$-diol 3-O- $\alpha$-L-rhamnopyranosyl- $(1 \rightarrow 4)-\alpha$-L-rhamnopyranosyl- $(1 \rightarrow 4)-[(1 \rightarrow 2)-\alpha-$-L-rhamnopyranosyl]- $\beta$-Dglucopyranoside.

The known compounds were identified as (25R)-spirost-5ene-3 $\beta$-ol 3-O- $\alpha$-L-rhamnopyranosyl- $(1 \rightarrow 4)$ - $\alpha$-L-rhamnopyranosyl-( $1 \rightarrow 4)$ - $\beta$-D-glucopyranoside $(3)$ [12], (25R)-7-oxo-espirost5-ene-3 $\beta$-ol 3 -O- $\alpha$-L-rhamnopyranosyl- $(1 \rightarrow 4)$ - $\alpha$-L-rhamnopyranosyl-( $1 \rightarrow 4)$-[( $1 \rightarrow 2)$ - $\alpha$-L-rhamnopyranosyl]- $\beta$-D-glucopyranoside (Chonglouoside SL-5) (4) [13] and (25R)-espirost-5-ene-3 $\beta$-ol 3-O- $\alpha$-L-rhamnopyranosyl- $(1 \rightarrow 4)$ - $\alpha$-L-rhamnopyranosyl- $(1 \rightarrow 4)$ [(1 $\rightarrow 2)$ - $\alpha$-L-rhamnopyranosyl]- $\beta$-D-glucopyranoside (5) [14] after extensive NMR spectral data analysis and comparison of its spectroscopic data with those reported in the literature.

The isolation of steroidal saponins is already reported for several species of different genera of Solanaceae as spirostane, furostane and spirofurostane sapogenins skeletons [21-24]. Although a large number of compounds belonging to the ${ }^{5} \Delta$-spirostane series have been reported, the structure of ${ }^{6} \Delta$-spirostane skeleton as observed for compound $\mathbf{2}$, is a feature never reported for this class of compounds. In addition, the uncommon hydroxylation at C-26 on the six membered pyran ring observed for $\mathbf{1}$ is noteworthy.

The structure-cytotoxicity relationship of steroidal saponins has been discussed and it has been established that aglycone played an important role in biological activity, while the type, length, linkage as well as the substituents of the glycosyl chain influenced the cell recognition and regulation of biological activity [25]. A literature survey has revealed that the cytotoxic activity of formosanin C (5) has been well documented and it has recently emerged as potential antitumor agent [26-28].
Compounds 1-5 were evaluated against four human cancer cell lines colorectal adenocarcinoma (HCT-116), ovarian carcinoma (OVCAR-8), human promyelocytic leukemia (HL-60) and glioma (SF-295) (Table 2). As expected, our results showed compound 5 as the most active showing effective action against all tested cell lines with $\mathrm{IC}_{50}$ ranging to 0.6 to $2.4 \mu \mathrm{g} \mathrm{mL} \mathrm{L}^{-1}$. Compound 1 exhibited a moderate effect against HL-60 and SF-295, compound 2 exhibited a selective activity against HL-60 with a $\mathrm{IC}_{50}$ value of $7.3 \mu \mathrm{g} \mathrm{mL}^{-1}$, compound 4 showed moderated activity to all cell lines, while compound $\mathbf{3}$ was inactive. The antimicrobial activities of the isolated compounds against $C$. parapsilosis $\left(\right.$ ATCC $^{\circledR} 22019^{\mathrm{TM}}$ ), C. albicans (ATCC $\left.{ }^{\circledR} 10231^{\mathrm{TM}}\right)$, C. krusei $\left(\right.$ ATCC $\left.^{\circledR} 14243^{\mathrm{TM}}\right)$, P. aeruginosa $\left(\right.$ ATCC $^{\circledR} 9027^{\mathrm{TM}}$ ), S. aureus $\left(\operatorname{ATCC}^{\circledR} 6538^{\mathrm{TM}}\right.$ ) and B. subtilis $\left(\mathrm{ATCC}^{\circledR}\right.$ $6633^{\mathrm{TM}}$ ) were evaluated. The results showed that only formosanin $C(5)$ presented antifungal activity against $C$. parapsilosis and $C$. albicans with values of $\mathrm{IC}_{50}$ values of 3.2 and $1.9 \mu \mathrm{g} \mathrm{mL}^{-1}$, respectively, while compounds 1-4 were inactive.

These findings can suggest that the $(1 \rightarrow 2)-\alpha$-L-rhamnopyranosyl linkage of the inner glucosyl moiety can be important for cytotoxic activity, since the compound $\mathbf{3}$ was inactive in all cancer cell lines and microorganisms. The modifications on the diosgenyl aglycone structure by the introduction of a hydroxyl group at C-26 on compound $\mathbf{1}$, one carbonyl group at C-6 on 4, or changes of the double bond in the ${ }^{6} \Delta$-spirostene skeleton showed only weak cytotoxic results, and no antimicrobial activities were observed.

\section{Conclusion}

The isolation of spirastone glycosides in C. laevigatum is in accordance with the previous reports about the Cestrum genus and the Solanaceae family. However, the occurrence of a ${ }^{6} \Delta$-spirostane skeleton is an unprecedented feature in the literature. The cytotoxic activity against HCT-116, OVCAR-8, HL-60 and SF-295 cancer cell lines showed formosanin $C(\mathbf{5})$ as the most active against all cell lines, while compounds $\mathbf{1}$ and $\mathbf{2}$ showed moderated activity against HL-60. Formosanin C (5) also showed selective antimicrobial effects against $C$. parapsilosis and $C$. albicans while compounds 1-4 were inactive. The current results suggest that the Cestrum genus is an important source of structurally interesting and biologically active steroidal saponins.

\section{Acknowledgements}

The authors are grateful to CNPq/CAPES/PRONEX/FUNCAP for the fellowships and financial support. We also thank to CENAUREMN of Universidade Federal do Ceará and Embrapa Agroindustria Tropical-CE for NMR and high-resolution mass spectra, respectively. 


\section{Appendix A. Supplementary data}

Supplementary data associated with this article can be found, in the online version, at http://dx.doi.org/10.1016/j.steroids.2015.12. 006.

\section{References}

[1] A.T. Hunziker, South American Solanaceae, a synoptic survey, in: J.G. Hawkes, R.N. Lester, A.D. Skelding (Eds.), The Biology and Taxonomy of the Solanaceae, Academic Press, New York, 1979, pp. 49-86.

[2] M. Nee, An overview of Cestrum, in: R.G. Van der Berg, G.W.N. Barendse, Van der Weeden, C. Mariani (Eds.), Solanaceae V: Advances in Taxonomy and Utilization, Nijmegen University Press, Nijmegen, 2001, pp. 109-136.

[3] M. Haraguchi, Y. Mimaki, M. Motidome, H. Morita, K. Takeya, H. Itokawa, A. Yokosuka, Y. Sashida, Steroidal saponins from the leaves of Cestrum sendtenerianum, Phytochemistry 55 (2000) 715-720.

[4] F.T. Baqai, A. Ali, V.U. Ahmad, Two new spirostanol glycosides from Cestrum parqui, Helv. Chim. Acta 84 (2001) 3350-3356.

[5] Y. Mimaki, K. Watanabe, H. Sakagami, Y. Sashida, Steroidal glycosides from the leaves of Cestrum nocturnum, J. Nat. Prod. 65 (2002) 1863-1868.

[6] M.A. Fouad, K.M. Mohamed, M.S. Kamel, K. Matsunami, H. Otsuka, Cesdiurins I-III, steroidal saponins from Cestrum diurnum L., J. Nat. Med. 62 (2008) 168173.

[7] M. Galarraga, M. Elier, A. Anne-Claire, T. Miyamoto, C. Tanaka, L. Pouysegu, S. Quideau, L.B. Rojas, M. Lacaille-Dubois, Steroidal saponins from the fruits of Cestrum ruizteranianum, Nat. Prod. Commun. 6 (2011) 1825-1826.

[8] M.D.C. Madureira, A.P. Martins, M. Gomes, J. Paiva, A.P. Cunha, V. Rosário, Antimalarial activity of medicinal plants used in traditional medicine in S. Tomé and Príncipe islands, J. Ethnopharmacol. 81 (2002) 23-29.

[9] M. Pennacchio, L. Jefferson, K.H. Medard, E. Welch, Uses and Abuses of Plantderived Smoke: Its Ethnobotany as Hallucinogen, Perfume, Incense, and Medicine, Oxford University Press, United Kingdom, 2010. p. 264.

[10] C.H. Tokarnia, M.F. Brito, J.D. Barbosa, P.V. Peixoto, J. Dobereiner, Plantas Tóxicas do Brasil, Rio de Janeiro: Ed. Helianthus; 2012, p. 566.

[11] J.D. Barbosa, C.M.C. Oliveira, C. Pinheiro, C.T.A. Lopes, D. Marquiore, M.F. Brito, E.M. Yamasaki, C.H. Torkania, Intoxicação por Cestrum laevigatum (Solanaceae) em bubalinos, Pesq. Vet. Bras. 30 (2010) 1049-1052.

[12] C.H. Sun, W. Ni, Z.H. Liu, L. Yang, Y.A. Si, Y. Hua, C.X. Chen, L. He, J.H. Zhao, H.Y. Liu, Steroidal saponins with induced platelet aggregation activity from the aerial parts of Paris verticillata, Steroids 92 (2014) 90-95.

[13] X. Qin, D. Sun, W. Ni, C. Chen, Y. Hua, L. He, H. Liu, Steroidal saponins with antimicrobial activity from stems and leaves of Paris polyphylla var. yunnanensis, Steroids 77 (2012) 1242-1248.
[14] H. Yu, X.W. Han, X. Liu, B. Yu, Y.Z. Hui, X. Bao, NMR studies on synthesized diosgenyl saponin analogs, Magn. Res. Chem. 38 (2000) 704-706.

[15] K.Y. Jung, J.C. Do, K.H. Son, The Structures of two diosgenin glycosides isolated from the subterranean parts of Allium fistuiosum, J. Korean Soc. Food Sci. Nutr. 22 (1993) 313-316.

[16] T.J. Mosmann, Rapid colorimetric assay for cellular growth and survival: application to proliferation and cytotoxicity assays, J. Immunol. Methods 65 (1983) 55-63.

[17] Performance Standards for Antimicrobial Disk Susceptibility Tests. Approved Standard M02-A11, Clinical and Laboratory Standards Institute, Wayne, 2012.

[18] Reference method for broth dilution antifungal susceptibility testing of yeasts Approved standard M27-A3. Wayne: Clinical and Laboratory Standards Institute; 2008.

[19] J.B.A. Neto, C.R. da Silva, F.B.S.A. Nascimento, L.S. Sampaio, A.R. da Silva Screening of antimicrobial metabolite yeast isolates derived biome Ceara against pathogenic bacteria, including MRSA: antibacterial activity and mode of action evaluated by flow cytometry, Int. J. Curr. Microbiol. Appl. Sci. 4 (2015) 459-472.

[20] P.K. Agrawal, D.C. Jain, R.K. Gufta, R.S. Thakur, Carbon-13 NMR spectroscopy of steroidal sapogenins and steroidal saponins, Phytochemistry 24 (1985) 24792496.

[21] S. Whankhede, M. Saxena, B. Yadav, Determination of triterpenoids (Quillaja saponaria Molina) from roots of Whitania somnifera (1.) dunal by high performance liquid chromatography, Asian J. Chem. 23 (2011) 693-696.

[22] C.L. Lee, T.S. Hwang, J.C. Yang, H.T. Cheng, W.T. He, C.T. Yen, C.L. Kuo, C.J. Chen, Anti-inflammatory spirostanol and furostanol saponins from Solanum macaonense, J. Nat. Prod. 77 (2014) 1770-1783.

[23] M. Iorissi, V. Lanzoti, G. Ranalli, Marino S. De, F. Zollo, Antimicrobial furostano saponins from the seeds of Capsicum annuum L. var. acuminatum, J. Agric. Food Chem. 50 (2002) 4310-4316.

[24] I.A. Nwabunike, A.C. Ezike, N.J. Nwodo, S.U. Udegbunam, C.O. Okoli Bioactivity-guided studies on the antiinflammatory activity of extract of aerial parts of Schwenckia americana L. (Solanaceae), J. Med. Plant Res. 8 (2014) 794-801.

[25] S.L. Man, Y.L. Wang, Y.Y. Li, W.Y. Gao, X.X. Huang, C.Y. Ma, Phytochemistry, pharmacology, toxicology, and structure-cytotoxicity relationship of Paridis rhizome saponin, Chin. Herbal Med. 5 (2013) 33-46.

[26] A. Yokosuka, Y. Mimaki, Steroidal glycosides from the underground parts of Trillium erectum and their cytotoxic activity, Phytochemistry 69 (2008) 2724 2730.

[27] X. Xiao, J. Zou, T.M. Bui-Nguyen, P. Bai, L. Gao, J. Liu, S. Liu, J. Xiao, X. Chen, X. Zhang, H. Wang, Paris saponin II of Rhizoma paridis - a novel inducer of apoptosis in human ovarian cancer cells, BioSci. Trends 6 (2012) 201-211.

[28] S. Man, W. Gao, Y. Zhang, C. Ma, L. Yang, W. Li, Paridis saponins inhibiting carcinoma growth and metastasis in vitro and in vivo, Arch. Pharm. Res. 34 (2011) 43-50. 